\title{
"A Study on Stress of Higher Secondary School Teachers In Relation To the Academic Achievement of Their Students"
}

\author{
Brintha.S, Dr.K.S. Ramakrishnan \\ M.com M.Phil, M.Ed M.Phil (Ph.D) Assistant Professor, Sri MuthuKumaran College of Education, Chennai - 69 \\ (Research Supervisor) Assistant Professor, Tamilnadu Open University Chennai - 60005
}

\begin{abstract}
A country's future is inextricably linked with its higher education system, which is in turn dependant on the quality of its teachers. A teacher is expected to act as a surrogate parent and yet function as an instructor, clarifier, expertly judge achievements, assess, moralise, legislate, judge, ethically precept, counsel, police and yet befriend a student in a constructive role. A teacher should lead students in their search for knowledge and wisdom and not act as an officer to be blindly obeyed. It is therefore recognizable that a teacher whose soul is worked whose heart is atrophied, devoid of zeal and energy due to 'STRESS' will not be able to satisfactorily perform their duties assigned to them by the society at large. Hence a teacher has to be multifaceted enough to shake off the 'Shackles of Stress' even under contradictory situations, if a healthy, well taught society is to emerge in future. In keeping with the job, the teacher is exposed to diverse expectations from his reference groups, such as principal, colleagues, pupils, society etc. Contradictory role expectations from reference groups could create role pressures, which means, experiencing stress. Wider social factors like low salary, inadequate training, low esteem of profession, constant changes in the organizational machinery, treat of school closure and the like, also function as stressors. The demand for skill and finesse disproportionate with the options available for situational training, appreciation and value of this work in society coupled with poor rewards at the end point exerting stress due to inefficiency and a feeling of inadequacy when career growth prospects are restricted and conditions of work are deplorable, teachers are cornered into a situation which is desperate yet not viable for counseling or tailor-made help.
\end{abstract}

Key Words: stress, teachers, academic achievement, students

\section{INTRODUCTION:}

'Stress' is a factor whose origin in one phase can influence other spheres of performance effectively. Excellence and stress are literally synonymous. Stress if controlled and reined-in can upgrade quality of performance. If allowed to rule over can thwart performance, spoil interpersonal relationships and affect the health of the individual. It therefore, implies that 'Stress in Teaching' is to be cautiously noted, as against 'Teacher's Stress' since the former has wide application on professional basics in teaching. Time has been defined as a very important stressor for teacher (Cook, 1992, Fletcher \& Payne, 1992). Cater in 1997 \& Cook (1992 ) The authors also identified that there is perception of lack of time, as stressor is directly proportional to the infringement of school related work on personal time'. The number of pupils, spatial arrangements, classroom size also feature as work related stressors (Dunham, 1996), Kanga and Flynn (1991) explain how, inappropriate spatial closeness could imply invasion of an individual's personal space forcing proximity at the expense of face to face interactions at every juncture. There are some sources of stress viz., Physical Stressors, Financial Stressors, Environmental Stressors and Organizational Stressors.

\section{NEED FOR THE STUDY:}

The stress in teachers affects the students' Academic Achievement and creates a deeper stress on the part Education of the students. Stress can be transformed into positive attitude so as to create a healthy atmosphere between the Teacher and the Students. Thus a study on "Stress of Higher secondary School Teachers in Relation to the academic achievement of their Students" was conducted in Chennai. The magnitude of stress that has a severe impact on both teachers and students is being studied by the researchers. The felt need focuses on the positive nature of stress to act as a stimulant.

OBJECTIVES: The objectives of the study were to

* Study the significant difference between men and women teachers in stress experience.

* Denote significant difference between Government and Government aided higher secondary school teachers in their stress experience. 
* Specify the intercorrelationship between stress experience of teachers and their students' academic achievement.

* Study the significant association between stress experience scores, of higher secondary school teachers and their age level.

\section{Hypotheses}

$>\quad$ There is no significant difference between men and women teachers with regard to their stress experience.

$>\quad$ There is no significant difference between Government and Government aided higher secondary school teachers in their stress experience.

$>\quad$ There is no intercorrelationship between the stress experience of teachers and their students' academic achievement.

$>\quad$ There is no significant association between stress experience scores, of higher secondary school teachers and their age level.

\section{DESIGN OF THE STUDY:}

The main objective of this investigation was to find out the significance of the relationship of stress with respect to gender, different types of schools namely Government and Government Aided and Higher secondary schools. The variables under this study include academic achievement of the students, teachers' qualification, grade level taught, subjects handled and level of experience. Based on the objectives and considering the variable under the study, the sample and tools were selected. After data collection research design was adopted to test the hypotheses of relationship and the hypotheses of variance.

\section{Achievement}

The quarterly examination marks in different subjects were collected from different type of school authorities to analyze the academic achievement of students.

\section{METHODOLOGY:}

The Investigators chose two types of schools in Chennai City. Four schools of each category were chosen. (Government, Government Aided) and a questionnaire was administered to 400 teachers of the schools. The data thus collected was subjected to statistical analysis.

TABLE 1 -SAMPLE DISTRIBUTION

\begin{tabular}{|c|l|c|c|c|}
\hline $\begin{array}{c}\text { S. } \\
\text { No }\end{array}$ & \multicolumn{1}{|c|}{$\begin{array}{c}\text { Type of the } \\
\text { School }\end{array}$} & $\begin{array}{c}\text { No. of } \\
\text { Male } \\
\text { Teachers }\end{array}$ & $\begin{array}{c}\text { No. of } \\
\text { Female } \\
\text { Teachers }\end{array}$ & Total \\
\hline 1. & Government & 100 & 100 & 200 \\
\hline 2. & $\begin{array}{l}\text { Government } \\
\text { Aided }\end{array}$ & 100 & 100 & 200 \\
\hline & \multicolumn{2}{|l}{} & 200 & 400 \\
\hline
\end{tabular}

\section{TABLE 2 -STRESS SCALE PatTERN}

\begin{tabular}{|c|c|c|}
\hline S.No. & $\begin{array}{c}\text { Name of the } \\
\text { Category }\end{array}$ & Item No. \\
\hline 1. & Mild Stress & $1-17$ \\
\hline 2. & Moderate Stress & $18-35$ \\
\hline 3. & Severe Stress & $36-52$ \\
\hline
\end{tabular}

Statistical ANAlysis: Mean and standard deviation were computed, based on which t-test was calculated.

\section{RESULTS OF THE HYPOTHESES:}

Hypothesis: 1 There is no significant difference between men and women teachers in stress experience. The obtained ' $t$ ' value is greater than the table value at.05 level of significance. Hence "Men and Women teachers differ in their stress experience, the null hypotheses is thus rejected. From the table it has been found that Male teachers have higher level of stress experience than Female teachers.

Hypothesis: 2 There is no significant difference between Government and Government aided school teachers in their stress experience.

The obtained't' value is lesser than the table value. Hence the hypothesis, "Government, Government Aided School teachers do not differ in their stress experience scores" is accepted. It is concluded that stress remfactor for ains the recommended Government and Government Aided school teachers.

TABLE 3 - Mean and Standard deviation and ' $T$ ' value for stress experience score of Men and Women teachers,

Government and Government aided school teachers

\begin{tabular}{|c|c|c|c|c|c|c|}
\hline S.No & Category & $\mathbf{N}$ & Mean & S.D & 't' Value & Remarks \\
\hline 01. & Male & 100 & 130.05 & 11.52 & 3.12 & SD \\
& Female & 100 & 125.99 & 10.92 & 11.83 & 0.92 \\
\hline 02. & Government & 100 & 127.46 & NSD \\
\hline
\end{tabular}


\begin{tabular}{|l|c|c|c|c|c|c|}
\hline & Government Aided & 100 & 125.96 & 10.73 & & \\
\hline
\end{tabular} Hypothesis: 3 There is no relationship between stress experience scores of higher secondary school teachers and the dent academic achievement of their students.

The Obtained " $r$ " value is more than the table value at 0.05 level significance. Hence the hypothesis is not accepted and it is concluded that there is relationship between the stress experience scores of higher secondary school teachers and their student academic achievement scores.

Hypothesis:4 There is no significant association between stress experience scores of teachers and their age level.

With $\mathrm{df}=4 . \chi^{2}-$ Value is significant at .05 levels. The teachers stress experience has significant influence on their age level.

\section{Bar - Diagram Show in the MEAN and STANDARD DEviation of Stress Experience Scores of Male and Female} Teachers, Government and Government aided school teachers

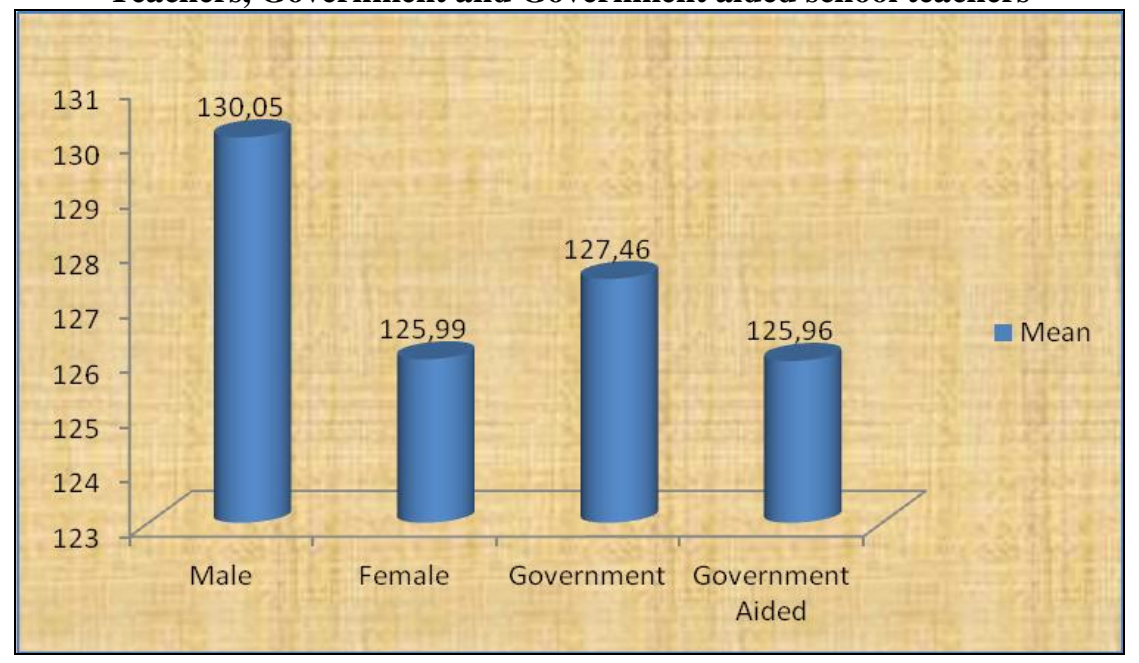

\section{DISCUSSION OF THE RESULTS:}

Based on the results obtained through statistical analysis of the data, it is concluded that

Stress of School Teachers have an impact on the Academic Achievement of the students women teachers have more total stress experience than men teachers.

It is concluded that there was relationship between the stress experience scores of higher secondary school teachers and their student academic achievement scores.

\section{CONCLUSION:}

In the modern world technology is at its peak, life seems to be synonymous with the word "Stress". It is an integral part of every human being's system, immaterial of changing day-to-day situations. The bygone past has also acknowledged Stressful events as important components of further progressive thinking and action. There are innumerable factors that can effectively contribute to the Stress levels of teachers in particular.

Education system around the world is under increasing pressure to use the modern techniques. It is to enhance the knowledge and skills of the students in the ensuing years of the $21^{\text {st }}$ century. These techniques could bring down the stress scores of the teachers and the Teachers must understand their importance in the process if the students have to achieve higher academically.

\section{References:}

[1] Abu Saad, Ismael, Organizational Climate and Teachers Job Satisfaction in the Bedouin elementary Schools of Negev in Southern Israel,0 Dissertation Abstracts International, 50, 9 March 1990, 2712-A.

[2] Bailse, J.J. A Social Psychological Grounded Theory of Teachers Stress and Burnout Education Administration Quarterly, Vol. 19(4), 1982, pp. 93-113.

[3] Darji. D.R.A. Study of Leadership Behaviour and Its Correlates in the Secondary Schools of Pachmals District, Second Survey of Research in Education. M.B.Buch (Ed), 40, Sep. 1979, p. 466.

[4] Edgarton, S.K. Teachers in Role Conflict. The Hidden Dilemma. Phi Delta Kappan, 59, 1977, pp. 120-122.

[5] Frey d, and Young J.A. Methods Administrators can use to help Teachers Manage Stress, NASSP Bulletin (67) 461, p. 73-77, 73.

[6] Gakhar, S., Markanda, S., Pautela, R. Job Satisfaction Among Primary, Middle and Secondary School Teachers. Journal of the Institute of Educational Research, Vol.8, No.2, May 1984

[7] Hinton, M.G. Teaching in large Schools, Headmasters Association Review, Vol. LXXII, No. 220, 1974, pp.17-19. 